\title{
Customers' Switching Behaviour in the Banking Industry in Cape Coast Metropolis, Ghana
}

\author{
Godfred Bugyei \\ Master of Commerce, Assistant Director, Ghana Education Service
}

\begin{abstract}
Deregulation, intense competition and the banking sector crises in Ghana has led to increased customer switching. It has, therefore, become crucial not just to attract every potential customer, but also to develop strategies aimed at maintaining the existing customers. This study sought to investigate the factors that affect the switching behaviour of customers in the banking industry in Ghana. Data for this study was obtained using self-administered questionnaires from 500 bank customers. A descriptive cross-sectional survey was adopted for the study. Binary logistic regression technique was used to analyse the data. The results revealed a significant relationship between customers' switching behaviour and the variables of interest, including, price, advertising, reputation, distance to bank location, switching cost and innovative products offered by banks. The study recommends that banks should embark on effective advertising campaign about the benefits of their products and improve upon their reputation. Banks should invest in technology and reduce their investment in bricks and mortar type of banking structures.
\end{abstract}

Keywords: Banking, Customer Switching Behaviour, Ghana

DOI: $10.7176 / \mathrm{JMCR} / 61-01$

Publication date:October $31^{\text {st }} 2019$

\section{INTRODUCTION}

Internationalization trends as a result of intense competition in the banking industry has led to increase in the level of customer satisfaction (Salih, Mustafa \& Ceyhun, 2012). Blankson, Cheng and Spears (2007) opine that increased competition resulting from a decade of deregulation of the financial services industry meant that banks have to differentiate their organizations and their offering from others as a way of attracting more customers. According to Clemes (2010) price, reputation, service quality, effective advertising, involuntary switching, distance, and switching costs impact customers' bank switching behaviour. In the financial service industry, customers are known to switch institutions after they have faced a single or multiple problems. Moreover in the banking industry unlike other financial institutions, customers are not bonded to any contractual relationship biding them to stay with the same bank forever (Gerrard \& Cunningham, 2004).

Many of the changes in the international banking environment are also evident in Ghana. A key development in the banking industry in Ghana was the deregulation of the sector. This led to the entry of a lot of foreign banks into the industry and the expansion of the branch networks by their indigenous counterparts.

In recent years, the banking sector in Ghana has undergone significant transformation and the central bank continues to develop new regulations and guidelines with the aim of maintaining stability in the financial market.

The Central Bank of Ghana (BOG) through a directive issued on 11 September, 2017 increased the stated minimum capital requirement for universal banks operating in Ghana from GHS120 million to GHS 400 million. The BoG stated, that it is to "further develop, strengthen and modernise the financial sector to support the Government's economic vision and transformational agenda". The universal banks were required to comply by this directive by December, 2018. The regulator has consequently, taken actions against the troubled banks and those which could not meet the minimum capital requirement (http/www.ghanaweb.com.gh).

On August 14, 2017, the Central Bank of Ghana (BOG) in its press release announced the approval of takeover of two indigenous banks namely UT and Capital Bank by GCB Bank Limited. The Bank of Ghana cited insolvency, related party transactions and bad corporate governance as the main reasons for the revocation of the licenses of the banks in question (Bank of Ghana, 2017).

Subsequently, on August 1, 2018, the Central Bank of Ghana, again announced the consolidation of five indigenous banks to form a new bank called Consolidated Bank of Ghana Limited. These collapsed banks included uniBank, Royal Bank, Sovereign Bank, Construction Bank and Beige Bank Limited. The same reasons for the purchase and assumption of UT and Capital bank were cited by the regulator for the consolidation of these five banks (Bank of Ghana, 2018).

Not only but also, on August 15, 2019, the Central Bank of Ghana revoked the operating licenses of 23 Savings and Loans Companies for bad corporate governance, insolvency and engaging in related party transactions (http/www.ghanaweb.com.gh).

It is, therefore, imperative for us to find out how the situation will affect the switching behaviour of bank customers in Ghana. Various studies have been carried out in the developed countries regarding the switching behavior of bank customers. However, only few empirical studies have been carried out regarding switching behaviour of customers in the developing world (Clemes, 2007). 
This gap generates an interesting proposition for investigation. The study, therefore, seeks to find out how price, reputation, switching cost, advertising, distance to bank location and innovative products affect the switching behaviour of customers in the banking sector in Ghana, particularly, in the Cape Coast Metropolis.

\section{REIEW OF RELATED LITERATURE}

\subsection{The Theoretical Foundation}

This section discusses the theoretical literature of the study and the empirical studies on determinants of bank customers' switching behaviour. The pertinent theoretical expositions underpinning this study are the rational choice theory and competition theory.

The rational choice theory offers a useful understanding on the selection behaviour of individual customers, while the competition theory elucidates how business organisations such as banks try to attract and gain the commitment of customers by offering innovative products and services. The rational choice theory is a charter for appreciating and formally modeling social and economic behaviour. The theory postulates that individuals make informed decisions by trying to maximize their benefits and minimize their costs. In other words, people make rational decisions by comparing the costs and benefits of different courses of action. Rational decision making requires choosing an action based on one's preferences, accomplishments and expectations about the outcomes of specified activities. The prudence of rational decision making is entrenched on two corresponding conventions, namely, completeness and transitivity. Completeness requires that all actions of the individual can be ranked in an order of preference, while transitivity is a condition that if choice $\mathrm{X}$ is preferred to $\mathrm{Y}$, and action $\mathrm{Y}$ is preferred to $\mathrm{Z}$, then $\mathrm{X}$ is preferred to $\mathrm{Z}$. The importance of rational choice theory in this case, is where customers compare the costs and benefits of their actions in order to arrive at an optimum decision with respect to switching from localowned bank to a foreign-owned bank and vice versa. Since bank customers want safety of their investment and to get worthwhile products and services at the lowest price and convenient location, they will judge the benefits of certain banks services to the other (Aregbeyen, 2011)

Competition in economics is best described as the existence within a market for some good or service of a sufficient number of buyers and sellers such that no single market participant has enough influence to determine the prevailing price of the good or service. Competition occurs when two or more organisations act independently to supply their products to the same group of consumers. Most banks operating in Ghana offer similar products to their customers. It is, therefore, easy for customer to switch from one bank to another when the customer is dissatisfied or the distance to his or her primary bank location is not convenient and the reputation of the bank is at stake. Competition causes banks to develop new products, services and technologies, which would give consumers alternatives choices and better satisfaction. Thus, the competitive strategy of firms is dependent upon consumers' choice characteristics which tend to influence firms' productive decision towards the satisfaction of consumers" preferences. In general, people will choose the bank that they perceive provides the greatest reward or benefits at the lowest cost, given their preferences. Hull (2002) opines that the banking industry is highly competitive, with banks not only competing among each other, but also with non-banks and other financial institutions. Most bank products and services are easy to duplicate so they can only distinguish themselves on the basis of effective advertising, lower price and the quality of the product they offer to their customers. Subsequently, customers' retention is possibly an effective tool that banks can use to gain a strategic advantage and survive in today's intense competitive banking environment.

In conclusion, customers of financial service providers are known to switch between institutions after they face multiple problems or feel dissatisfied. Moreover, in the case of banks unlike other financial institutions, customers are not bonded to any contractual relationship of transacting business with the same bank forever. Banks therefore can use effective advertising, build good reputation and develop unique products and services to stay in business.

\subsection{Demographic Characteristics}

The demographic characteristics of customers can also influence their choice prospects. According to Quester, McGuiggan, \& Perrault (2007), customers' demographic characteristics can be grouped into age, income, education, Culture and nationality. In their study Clemes et al., (2007) observed that in New Zealand, younger aged customers are the most likely group to switch between banks. The type of occupation engaged in also affects the probability of consumers using electronic banking channels for financial transactions Gan, Clemes, Limsombunchai \& Weng (2006).

Colgate and Hedge (2001) opine that bank switching behaviour is highly common among younger, highincome, and highly educated customers than those customers in the older, low-income, and less-educated demographic groups. $\mathrm{Li}$ (2008) postulates that in China, the white-collar work group tends to switch banks because they earn high incomes and have a higher educational background. 


\subsection{Distance}

Location is a crucial factor that could determine the bank switching behaviour of customers. Convenient location of ATM and parking space are some of the factors that help to retain customers and attract more customers (Salleh \&Hazimah, 2009). People may prefer to select the nearest branch of a bank from either residential place or work place (Kisser, 2002).A convenient location can encourage customers to stay at their current bank and delay the idea of switching, even if the satisfaction rate is not high (Lee \& Cunningham, 2004). Location has special meaning in the financial service industry because it is at the branch or office that banks and their customers are connected (Peppard, 2000).

\subsection{Service Quality}

Quality of services are symbolized by politeness of the teller when dealing with customers, the ability of the teller to convey trust and confidence, efficiency of the service, and the ability of tellers to get the customer's problems solved. To improve upon the quality of service offered to customers, it is imperative that employees of banks are trained to know the ethics, professionalism and the basic responsibilities they have towards their customers. A better service quality will indubitably attract new customers and help to retain the existing customers, since customers of today are sophisticated. Service quality has positive relationship with customer switching behaviour (Safakli, 2007). Study by Abdullah (2007) documented that customer patronization in the Islamic bank in Malaysia depends on customer satisfaction which is highly correlated with the quality of service. Dusuki and Abdullah (2006) studied the main factors that motivate customers to select Islamic banks in Malaysia. Their finding disclosed that the level of service quality delivered by Islamic banks contributes to customer satisfaction, and influences customers' long-term support for Islamic banking. Lymperopoulos, Chaniotakis and Soureli (2006) also evaluated the relative importance of bank selection criteria used by bank customers. The results disclosed that efficient service quality and speed of transactions have significant positive influence on customers' bank selection decision. Price

Price is consideration of what one pays for the benefit or service he gets from another. The Pricing factors include interest on loans, rates, fees, service charges, interest on savings and deposits that can influence a customer to switch from one bank to another.

In the banking context, switching costs are the range of costs that bank customers incur if they wish to transfer their banking relationship, in part or in full, from one financial institution to another (Matthews \& Murray, 2007). Hazimah (2009) posits that price is ranked as the fifth of the nine factors that influence customers switching behaviour in Malaysia. Clemes, Gan and Kao (2007) opines that price did not influence the switching behaviour of customers in the New Zealand Banking Industry. Gerrard and Cunningham (2004) maintain that pricing influences switching behaviour among bank customers as price has a wider implication for bank customers than customers of other services.

\subsection{Reputation}

Reputation depends on three elements, namely the reliability of bank, trust worthiness of the bank, and the financial stability of the bank. A bank with bad reputation can loose customers since its customers will switch to the alternative bank which is financially stable Clemes, Gan and Zheng (2010). In his study Abdullah (2007) discovered that reputation was one of the factors that affect customer's switching behaviour in Malaysian Islamic Banking Sector. Thus, it is crucial for Islamic banks to boost their reputation by enhancing their public relation which includes two attributes such as Islamic reputation and image, and financial and economic reputation. Brand, contributions to charitable institutions, sponsorships of specific events may likely increase the reputation of a bank. Gerrard and Cunningham (2004) also affirms that bank reputation has an integrity on a bank, its senior executives and the bank's perceived financial stability. A good reputation can strengthen customers' trust and confidence in a bank, while a bad reputation can increase the probability of the decision to switch banks (Clemes et al., 2007).

\subsection{Advertising}

Advertising is defined as promoting the products or services of a brand or company for the purpose of letting the consumers know the existence of it. Advertising is important to all the banks in this highly competitive market and it seems to be the most popular way of marketing. Promoting the business through announcing various offers attract more customers. Advertising is promoting the products or services of a brand or company for the purpose of letting the consumers know the existence of it. Cengiz, Ayyilding and Bunyamin (2007) studied bank customers' behaviour in Turkey and found that efficient advertising may enhance a bank's customer loyalty and help retain customers. Attractions such as free gifts or lucky draw may help reduce the switching behaviour of customers (Gerrard\& Cunningham, 2004).

\subsection{Innovative Products}

According to Kotler (2003), innovation is described as any good, service or idea that is perceived by someone as 
new. Singhal and Padmanabhan (2008) aver that customer perception towards internet banking provides a comprehensive framework of various factors which contribute to customers' perception such as convenience, reliability, time factor, real time access to information, faster transfer, easy to use, user friendly, low transaction fee, anytime and anywhere banking facility, among several other factor. Rehman and Shaima (2008) conducted study in Pakistan. Bank customers in this country emphasized that three common and important factors including customer services, convenient location of ATM and on-line banking services influence their switching behaviour and bank selection decision.

\subsection{Switching Cost}

The existence of switching cost does have impact on market operation, profits and entry barriers. The influence of switching cost on customer behaviour is that as customers are bonded with their service provider, it becomes hard for them to change to a new provider. A study carried out by Matthews (2009) identified various elements of switching costs including learning costs, search cost, monetary loss, personal relationship, brand relationship, hassle and uncertainty. Lees, Garland and Wright (2007) observed that the direct and opportunity costs of switching may discourage customers from leaving their current organisation because customers may perceive switching costs to be higher than the expected benefits of changing service providers. Therefore, the following hypothesis is proposed:

H9. There is a negative relationship between switching costs and customers' switching banks.

In conclusion, determinates of customers' bank switching behaviour is important. Employment level, age and education, are the demographic factors that have impact on customers bank switching behaviour. Price, reputation, advertising, switching cost, and innovative products are the variables of interest which also have significant effect on the switching behaviour of customers. Banks in Ghana must seriously consider these factors when they plan and implement their marketing strategies.

\section{THE METHODOLOGY OF THE STUDY}

\subsection{Research and Sampling Design}

A descriptive cross-sectional design was adopted for the study. This was considered appropriate, since the study involved the description of determinants of customers' switching behaviour. Cohen, Manion and Morrison (2011) elucidate that descriptive design provides a meaningful picture of events under consideration. A systematic random sampling approach was adopted to distribute the questionnaire to the respondents. The respondents for the study were the customers of all the commercial bank operating in the Cape Coast Metropolis in Ghana. However, out of the eight banks marked down for the study, only four of them responded positively. The managers of the banks excluded from the study said that they had been authorized by their head office not to reveal information about their operations and customers to outsiders. The initial questionnaire consisted both closed and open-ended questions piloted on 150 bank customers. The questionnaire was fine-tuned and distributed to 600 bank customers. We retrieved 500 questionnaires from the respondents representing a response rate of $83.3 \%$.

\subsection{Characteristics of the Respondents}

Sixty nine percent of the respondents were males while thirty one percent were females. Majority of the respondents 415 representing 83\% were between 19 years and 49 years. Only 85 respondents, thus 17\% were above 50years. GCB Bank had about $40 \%$ of the sample, followed by Barclays $(30 \%)$ and Agricultural Development Bank (ADB) (16\%). Zenith Bank had the least number of respondents (14\%). This is not a startling revelation because GCB Bank is the oldest local-owned bank with two branches at the Cape Coast Metropolis. Barclays is the first foreign-owned bank established in the metropolis and operates two ATM points.

\subsection{Data Analysis Methods and Model specification}

Since the dependent variable is a dichotomous, the study used binary logistic regression model. Customers bank switching decision was the dependent variable. The generalized binary logistic regression technique was used to model unordered categorical response variables. This model allows each category of an unordered response variable to be compared to an arbitrary reference category. In this case the researcher considered local-owned bank as the base category since it holds the highest proportion of customers as compared to the foreign-owned banks based on the information gathered from the customers during the period of the study. The independent variables were selected based on theoretical literatures and empirical results of different studies on bank customers switching behaviour. The independents variables of interest adopted for the study are price, advertising, reputation, switching cost, distance to bank location and innovative products. Demographic variables such as age, employment level and education were used as control variables for the study. 


\subsection{Definition of variables and their measurement \\ 3.4.1 Dependent variable}

Customers' switching behaviour was the dependent variable and this variable is dichotomous.

3.4.2 Independent variables

Based on the study of theoretical and previous empirical results of different studies on customer's bank switching behaviour, demographic characteristics, price, advertising, service quality, distance, reputation, innovative products and switching cost are employed as the independent variables for this study.

\section{Results and Discussion}

In this section, binomial logistic regression estimates of customers switching behaviour between local and foreignowned banks are presents and discussed below.

The customers' decision to switch between banks is hypothesized to depend on demographic and socialeconomic variables. The demographic variables include age, educational level, and employment status of the customer. The social-economic variables include price, advertising, reputation, switching cost, service quality, distance to bank location, and innovative products offered by banks. The regression result is indicated in Table 2 . In all, responses from a cross section of 500 customers were used in this study. The result in Table 2 indicates that employment level, age, education, price, advertising, reputation, switching cost, service quality, distance to bank location and innovative products are significant predictors for the probability of a customer's decision to switch between local and foreign-owned banks.

Table 4.2 also presents the marginal effect of the variable of interest and other controlled variable adopted for the study. Most of the marginal effect figures demonstrate that certain case specific factors have strong and significant effect on the probability of the customer's decision to switch between local and foreign-owned banks.

The result from Table 4.2 indicates that holding all other variable constant, a customer who is employed is more likely to switch to local-owned bank from foreign-owned bank at $5 \%$ significant level. The marginal effect of $0.028 \%$ points to the fact that when the customer is employed the probability that the customer will switch to local-owned bank increases by 28 percentage point. This result corroborates the finding of $\operatorname{Li}(2008)$ that the whitecollar job group tends to switch banks because they earn high incomes and have a higher educational background.

Distance to bank location is also significant in explaining the probability of a customer switching between a local and foreign- owned bank. The marginal effect of 0.00690 indicates that a kilometer increase in the distance to the nearest bank branch increases the probability of a customer switching from foreign- owned bank to localowned bank by 0.69 percentage point. This implies that the longer the distance to the nearest foreign-owned bank branch, there is likelihood that a customer would switch to a local-owned bank at 0.69 percentage point. This results is consistent with the finding of Salleh and Hazimah (2009) that convenient location can influence customers to stay with their current bank and delay the idea of switching to a new service provider.

Service quality is also significant in explaining customers switching behaviour at $5 \%$ percent. The marginal effect of -0.0532 implies that a unit decrease in service quality by a foreign-owned bank increases the probability if a customer switching to a local-owned bank by 5.32 percentage point. This result confirms the finding of Safakli (2007) that service quality have positive relationship with customer switching behaviour.

Price was also found to be significant in explaining customers switching behaviour at $10 \%$ significant level. The marginal effect of 0.0495 implies that a unit increase in fees charged by foreign-owned banks increases the probability of a customer switching to a local-owned bank by 4.95 percentage point. This result confirms the finding of Hazimah (2009) that financial benefit and charges influence customer's switching behaviour in Malaysia. However, this result is inconsistent with the finding of Clemes (2007) that price did not influence the switching behaviour of customers in New Zealand bank industry.

Reputation is also significant in explaining customers' switching decision between local and foreign-owned banks at $1 \%$ significant level. The marginal effect of 0.0116 indicates that a unit increase in the reputation score increases the probability of customers switching from foreign-owned bank to local-owned bank by 1.168percentage point. Thus as the local-owned banks become financially stable the probability of the customers switching to them for financial transactions increases as compared to foreign-owned banks. This also indicates that customers of local-owned banks will be loyal to them as their reputation and the brand image become good. This result corroborates the finding of Clemes (2010) that a bank with bad reputation led to the tendency of bank switching by customers. This result is also inconsistent with finding of Aregbeyen (2011) that bank image and reputation are insignificant factors to customers switching behaviour.

Advertising is also significant in explaining customers' decision to switch between local and foreign-owned bank at $10 \%$ significant level. The marginal effect of 0.1178 indicates that a unit increase in banks advertising campaign increases the probability of customers switching from foreign-owned bank to local-owned bank by 17.70 percentage point. This result is consistent with the finding of Cengizet e tal. (2007) that advertising efficiency has a direct positive effect on bank image as well as customer expectation.

Innovative product offered by a bank is significant in explaining a customer's decision to switch between 
local and foreign-owned bank at $10 \%$. Thus as a local-owned bank introduces an innovative product to the market, it is expected to induce customers of a foreign-owned bank to switch to a local-owned bank. The marginal effect of 0.0150 indicates that an additional unit of innovative product is introduced by local-owned bank, it increases the probability of a customer switching from foreign-owned bank to a local-owned bank at 1.50 percentage point. This result is supported by the finding Rehman and Ahmed (2008) that convenience of ATM location and on-line banking services are the new methods of banking which are key determinant of customer's switching behaviour.

Switching cost also was also found to influence the switching behaviour of customers at 10 percentage point. The marginal effect of 0.0865 indicates that a unit increase in the rate and fess of a local-owned bank decreases the probability of a customer switching from a local-owned bank to a foreign-owned bank by 8.65 percentage point. This result is consistent with the finding Matthews (2009) that various elements of switching costs namely learning costs, search cost, monetary loss, personal relationship, brand relationship, hassle and uncertainty affect greatly the switching behaviour of bank customers.

\section{CONCLUTIONS}

The banking environment of today is rapidly changing and the financial sector reforms have encouraged the proliferation of banks in Ghana. The force of technology has led to the introduction of innovations in banking products which affect customers' bank switching behaviour. This study has revealed that there is general awareness of innovative banking products among customers in the Cape Coast Metropolis. ATM, internet banking and EZwich were the most popular innovative products among bank customers. Based on the regression result, bank customers generally demonstrate increased sensitivity to reputation, distance, innovative products, advertising, high fees and interest as the primary factors that influence them to switch between local and foreign-owned banks. Age, education, and other issues related to demography were also found to have impact on bank switching behaviour of customers in the Cape Coast metropolis in Ghana. Banks in Ghana should continue with the development of innovative products that are targeted at young people and middle income earners. Also, intensive advertising and public education should be done to inform the populace about the benefits of innovative banking products and services. Banks should also improve upon their brand image and financial stability to promote customer confidence to bank with them. Finally, banks should invest in modern technology and reduce the investment in bricks and mortar.

\section{References}

Arebgeyen, O. (2011). The Determinants of Bank Selection Choices by Customers: Recent and Extensive Evidence from Nigeria, International Journal of Business and Social Science, 2(22), 12-15.

Blankson C., Omar O. E., \&Cheng J. M. (2009). The Retail Bank Selection in Developed and Developing Countries: A Cross-National Study of Students' Bank Selection Criteria, Thunderbird International Business Review, 51(2), 183-98.

Cengiz. E., Ayyilding. H., \& Bunyamin. E, (2007). Effects of image and advertising efficiency on customer loyalty and antecedents of loyalty: Turkish banks sample, Bank and Bank Systems, 2(1).

Clemes, M.D., Gan, C. \& Zheng, L.Y. (2010). "Customer switching behaviour in the New Zealand banking industry", Banks and Banks System, 2(4), 50-66.

Clemes, M.D., Gan, C. and Kao, T.H. (2007). "University satisfaction: an empirical analysis", Journal of Marketing for High Education, 17(2), 292-325.

Clemes. M. D., Gan.C \& Zhang. D (2010). Customer switching behaviour in the Chinese retail banking industry, International Journal of Bank Marketing, 28(7), 519-546.

Colgate, M. and Hedge, R. (2001), "An investigation into the switching process in retail banking services", The International Journal of Bank Marketing, 19(4), 201-13.

Cohen, L., Manion C., \& Morrison, K. (2011).Research Methods in Education. Reoutledge

Dusuki. W. A \& Abdullah. I. N (2007). Why do Malaysian customers patronize Islamic banks?, International Journal of Bank Marketing, 25(3), 142-160.

Gan, C., Clemes, M., Limsombunchai, V. and Weng, A. (2006), “A logit analysis of electronic banking in New Zealand", International Journal of Bank Marketing, 24(6), 360-83.

Lees, G., Garland, R. and Wright, M. (2007). "Switching banks: old bank gone but not forgotten", Journal of Financial Services Marketing, 12(2), 146-57.

Li, C.L., (2008), "Profile of middle class in mainland China", available at:www.sociology.cass.net.cn/pws/lichunling/grwj_lichunling/P020090525597135469507.

Lymperopoulos C. Chaniotakis I. E., \& Soureli M. (2006), The Importance of Service Quality in Bank Selection for Mortgage Loans, Managing Service Quality, 16(4), 365-379.

Safakli. O. V (2007). A research on the basic motivational factors in consumer bank selection: evidence from Northern Cyprus, Bank and bank systems, 2(4), 10-13.

Gerrard. P \& Cunningham. B. (2004). Consumer switching behaviour in the Asian banking market. Journal of 
Services Marketing, 18(3), 215-223.

Hull (2002). Foreign-owned banks: Implications for New Zealand's financial stability. Discussion Paper Series, DP2002 (5).

Kiser, E.K. (2002). Household switching behaviour at depository institutions: Evidence from survey data; Federal Reserve Board, 20th and C ST., NW, Washington, DC 20551, (202) 451-2584.

Kotler, P. (2003). Marketing management. Upper Saddle River; New Jersey: Pearson Education. Leow, H. B. (1999). New distribution channels in banking Services. Banker's Journal Malaysia, 110, 48-56.

Matthews, C. (2009), Switching costs in banking: the regulatory response. Centre for Banking studies, Department of Economics and Finance

Quester, P.G., McGuiggan, R.I., Perrault, W.D. and McCarthy, E.J. (2007), Marketing: Creating and Developing Value, McGraw-Hill/Irwin, New York, NY.

Rao, A. S. (2010). Bank Selection Criteria Employed by MBA Students in Delhi: An Empirical Analysis, Journal of Business Studies, 1(2), 56-69.

Rehman, H.U., \& Saima, A. (2008). An empirical analysis of the determinants of bank selection in Pakistan: A customer view. Pakistan economic and social review, 46(2) 20-23.

Salih,T., Mustafa, P. \& Ceyhun, K. (2011). "Bank selection criteria in the banking industry": An empirical investigation from customers in Romanian cities African, Journal of Business Management, 5(14), 551-558.

Salleh, H. S. \& Hazimah, N. (2009). Commercial bank selection: comparison between single and multiple bank users in Malaysia, International Journal of Economics and Finance, 1 (2), 6-10.

Singhal, D., \& Padhmanabban, V. (2008). A study of customer perception toward internet banking: Identifying major contributing factors. The Journal of Nepalese Business Studies, 5(1), 101-111.

http://www.bog.gov.gh. Bank of Ghana. Retrieved (August 18, 2019).

http://www.ghanaweb.com. Accessed (August 20, 2019).

Zhang, D. (2009). "Customer switching behaviour in the Chinese retail banking industry", unpublished Master's thesis, Lincoln University, Canterbury

Appendix

Table1. Background of Respondents

\begin{tabular}{|c|c|c|}
\hline \multirow{2}{*}{\multicolumn{3}{|c|}{$\begin{array}{l}\text { Customer Characteristics } \\
\text { Sex }\end{array}$}} \\
\hline & & \\
\hline Male & 345 & 69.00 \\
\hline Female & 155 & 31.00 \\
\hline Total & 500 & 100.00 \\
\hline \multicolumn{3}{|l|}{ Age } \\
\hline $18-29$ & 125 & 25.00 \\
\hline $30-39$ & 197 & 39.40 \\
\hline $40-49$ & 93 & 18.60 \\
\hline 50 and above & 85 & 17.00 \\
\hline Total & 500 & 100.00 \\
\hline \multicolumn{3}{|l|}{ Educational Level } \\
\hline Basic School & 98 & 19.60 \\
\hline Secondary School & 134 & 26.80 \\
\hline Tertiary Education & 268 & 53.60 \\
\hline Total & 500 & 100.00 \\
\hline \multicolumn{3}{|l|}{ Employment status } \\
\hline Employed & 484 & 86.15 \\
\hline Unemployed & 26 & 13.85 \\
\hline Total & 500 & 100.00 \\
\hline \multicolumn{3}{|l|}{ Monthly Income } \\
\hline $50-499$ & 100 & 20.00 \\
\hline $500-999$ & 280 & 56.00 \\
\hline 1000 and above & 120 & 24.00 \\
\hline Total & 500 & 100.00 \\
\hline \multicolumn{3}{|l|}{ Banks } \\
\hline GCB Bank & 200 & 40.00 \\
\hline Barclays Bank & 150 & 30.00 \\
\hline Agricultural Development Bank & 80 & 16.00 \\
\hline Zenith Bank & 70 & 14.00 \\
\hline Total & 500 & 100.00 \\
\hline
\end{tabular}

Source: Field Survey, 2019 
Table 2. Regression Estimates for Determinants of Switching Behaviour

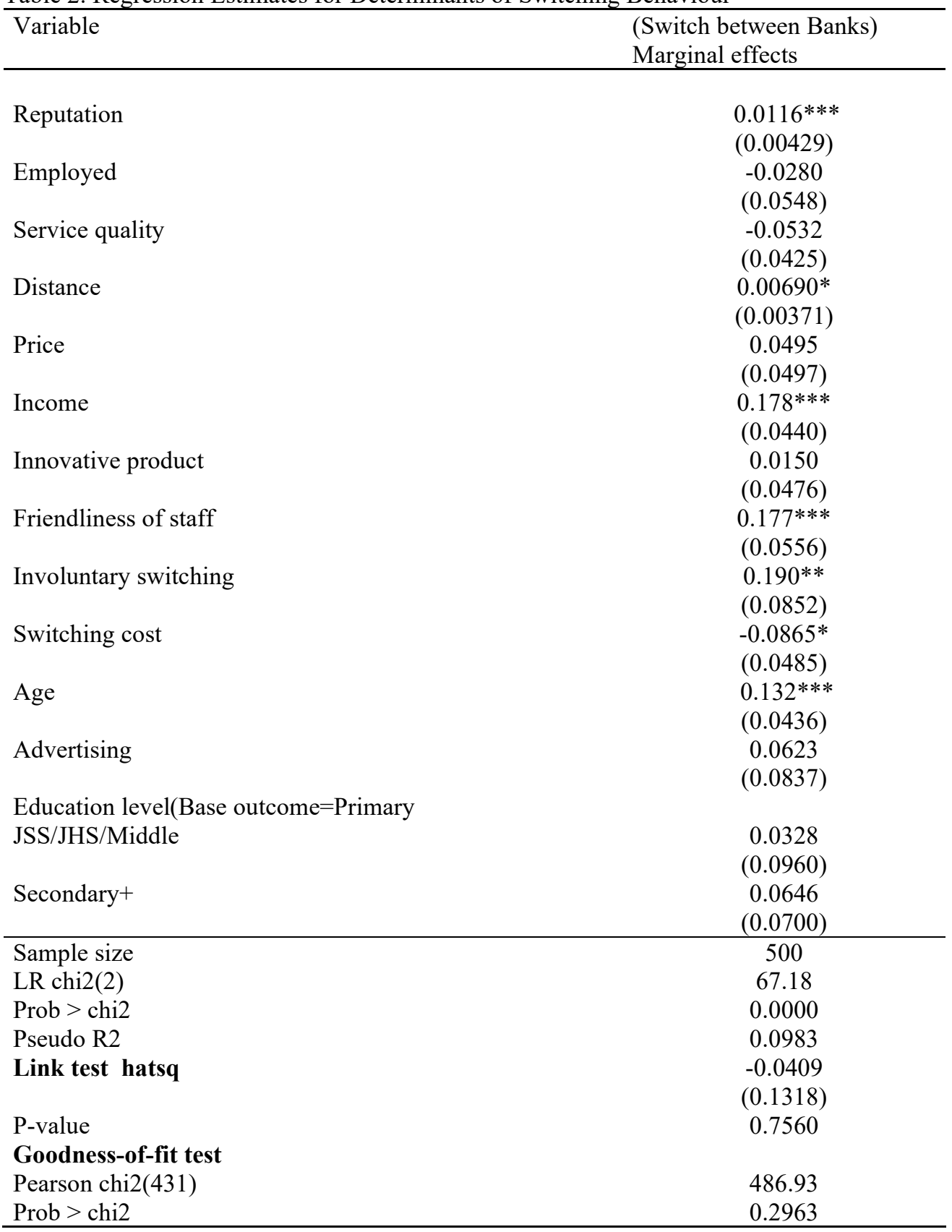

Prob $>$ chi 2

Source: Field Survey, 2019 